\title{
An Interesting Cytology and Histopathological Correlation of Adnexal Tumor
}

\author{
${ }^{1}$ Dr. K. Valarmathi, ${ }^{2}$ Dr. V. Palaniappan, ${ }^{3}$ Dr. Mary Lilly, ${ }^{4}$ Dr. Ramya \\ ${ }^{I}$ Professor of pathology Stanley medical college Chennai \\ ${ }^{2}$ Assistant professor of pathology Stanley medical college Chennai \\ ${ }^{3}$ Professor of pathology Stanley medical college Chennai \\ ${ }^{4}$ Post graduate of pathology Stanley medical college Chennai
}

\begin{abstract}
To have better correlation between the cytomorphologic and histomorphological features of pilomatrixoma $(P M X)$ which helps in arriving correct diagnosis of the lesion.

Keywords: Fine needle aspiration cytology, Histopathology,pilomatrixoma
\end{abstract}

\section{Case Report:}

A 25 year old male patient came with the complaints of slow growing swelling in the left forearm for the past one year duration. The swelling gradually increasing in size to reach the present size of $4 X 3 \mathrm{~cm}$ (Fig. 1). On examination the swelling measures about $4 \mathrm{X} 3 \mathrm{~cm}$ which was firm ,nodular and freely mobile. Skin over the swelling is not pinchable.Plain $\mathrm{x}$ ray were unremarkable . Fine needle aspirationr shows clusters of basaloid epithelial cells having round to oval nuclei admixed with shadow cells with eosinophilic cytoplasm with central unstained anucleated zone arranged in the background of foreign body giant cells and it was reported as pilomatrixoma(Fig 2,3). The swelling was subsequently excised and sent for histopathological examination.

Gross:

\section{Pathological Findings:}

Received an excision biopsy specimen of skin with underlying soft tissue measuring $4 \times 3 \times 2 \mathrm{cms}$.Cut surface shows grey white solid areas admixed with grey tan specks of calcified areas(Fig.4).

\section{Microscopy :}

Microscopically, skin with underlying lesion composed of basaloid epithelial cells and shadow cells in varying proportions. Basaloid cells shows dark staining nuclei and scanty cytoplasm. Shadow cells shows eosinophilic cytoplasm and a central-unstained (optically empty) zone. Areas revealing apparent evolution of basaloid cells into shadow cells were also noticed. The tumor stroma also shows granulomatous reaction with keratin debris, foreign body giant cells with areas of calcification and inflammatory cells(Fig.5).

\section{Discussion:}

Pilomatrixoma is a benign skin neoplasm covered by normal skin which is located in the dermis and subcutaneous tissue. Pilomatrixoma, or calcifying epithelioma of Malherbe, is a tumor which was origin from hair cells, particularly hair cortex cells. It occurs usually as a solitary lesion and it occur most commonly in face and upper extremities. Generally, the tumor varies in diameter from 0.5 to $3.0 \mathrm{~cm}$, but it may be as large as 5 $\mathrm{cm}$. The tumors may arise in persons of any age, but about $40 \%$ of them arise in children younger than 10, and about $60 \%$ in persons in the first two decades of life. ${ }^{1}$ It frequently presents as a firm, deep-seated nodule that is covered by normal skin. Occasionally, however, the tumor is more superficially located, causing a blue-red discoloration of the overlying skin, and, rarely, it protrudes as a sharply demarcated, dark red nodule. Rapid enlargement of a pilomatricoma may occur as a result of formation of a hematoma ${ }^{2}$.

Fine needle aspiration cytology showed distinctive cellular and non-cellular components, shadow cells, primitive-appearing basaloid cells with a high nuclear/cytoplasmic ratio, nuclei exhibiting evenly dispersed chromatin and foreign body giant cells . FNAC smears are aidsl in making a precise preoperative diagnosis of Pilomatrixoma. The presence of calcification and nucleated squamous cells further supports the diagnosis. However, the diagnostic triad of basaloid cells, ghost cells and foreign body giant cells need not necessarily be present in all the cases. When the aspirate happens to be from the periphery of the tumor or from an early lesion, it will show a marked predominance of basaloid cells at times to the extent of absence of other components. Aspirates from older lesions may even show only ghost cells. ${ }^{3,4}$

Lesions that mimic Pilomatrixoma are skin appendageal tumors are trichilemmal cyst, epidermal inclusion cyst, cylindroma, malignant neoplasms (squamous and basal cell carcinoma) and granulomatous lesions. ${ }^{5,6}$ Skin appendage tumors, such as cylindroma, eccrine spiradenoma and hidradenoma, contain mainly 
basaloid cells. Smears of these lesions show a predominance of basaloid cells in cohesive, smoothly contoured groups which contrast with the typically irregular, saw-toothed edges of the cohesive to loosely cohesive monolayer sheets of basaloid cells seen in Pilomatrixoma. Shadow cells, mature nucleated squamous cells and multinucleated giant cells may be present. Finding of occasional shadow cells on reexamination was the only pointer to further categorize adnexal tumor in this case.

Occasionally smear were misinterpreted as benign lesions (epidermal inclusion cyst, benign cystic lesion and fibrohistiocytic lesion) when it shows numerous keratinized squamous cells with scant basaloid cells admixed with shadow cells . Like Pilomatrixoma, epidermal inclusion cysts are often superficial in location, but are rubbery rather than hard on palpation and show a monomorphic population of delicate, well-delineated anucleated squamous cells that are present singly or in clumps with absence of Basaloid cells. Multinucleated giant cells and debris are not seen, provided that the needle has been placed at the core of the cyst. If the cyst wall has been broken, a possible foreign body granulomatous reaction may be observed. It is very rare for epidermal cysts to undergo calcification. ${ }^{7}$ Dominance of squames on aspirate is the main confusing factor that leads to erroneous diagnosis of epidermal inclusion cyst.

In the absence of shadow cells, the cytologic diagnosis of Pilomatrixoma may be difficult. The presence of shadow cells with characteristic central pale nuclear zone has been repeatedly reported in the literature as the most important cytologic feature for the diagnosis of Pilomatrixoma. ${ }^{8}$

Pilomatricomas are usually solitary, multiple lesions have been reported in association with genetic disorders, such as myotonic dystrophy, gardners syndrome, xeroderma pigmentosum and basal cell nevus syndrome. . $^{8}$

A granulomatous inflammation may be suspected if inflammatory cells and foreign body giant cells are predominant in the smears. Multinucleated giant cells in dermal aspirates may be observed in several conditions ranging from keratinous cysts, ruptured benign cysts, panniculitis to squamous cell carcinoma. To categorize the lesion, type of cells accompanying multinucleated giant cells should be given importance. In Pilomatrixoma, these cells correspond to a foreign body giant cell reaction adjacent to shadow cells. ${ }^{9}$

Certain features of the cytologic appearance of PMX are likely to cause confusion with malignancy. These include a high cellular yield, the presence of small primitive-appearing cells with a high nuclearcytoplasmic ratio, prominent nucleoli, nuclear molding, mitotic figures and a background rich in debris and inflammatory cells resembling tumor necrosis. Studies show that Pilomatrixoma has been very often misdiagnosed as carcinoma. ${ }^{10,11,12}$

The cytological presentation can be mistaken for squamous cell carcinoma because of high cellularity ,high nuclear cytoplasmic ratio and presence of anucleated squames. ${ }^{13}$

Features that aid in the recognition of a benign lesion include a bland and evenly distributed chromatin pattern, regular nuclear contours or membranes in the small, primitive, uniform cell population and lack of nuclear atypia in the squamous cells.

In conclusion, FNAC smears from a firm to hard swelling located in the head, neck or upper extremities presenting in a young adult should be examined carefully to exclude Pilomatrixoma. Most commonly diagnostic errors may arise due to predominance of one component over the others should always be in the mind of cytopathologist while examining FNAC smears to avoid incorrect diagnosis on cytology .

\section{References:}

[1]. Moehlenbeck FW. pilomatrixoma (calcifying epithelioma). A statistical study. Arch Dermatol 1973;108:532-534

[2]. 2.Swerlick RA, Cooper PH, Mackel SE. Rapid enlargement of pilomatricoma. J Am Acad Dermatol 1982;7:54-56.

[3]. Wang J, Cobb CJ, Martin SE, Venegas R, Wu N, Greaves TS. Pilomatrixoma: clinicopathologic study of 51 cases with emphasis on cytologic features. Diagn Cytopathol. 2002;27:167-72.

[4]. Layfield LJ, Glasgow BJ. Aspiration biopsy cytology of primary cutaneous tumors. Acta Cytol. 1993;37:679-88.

[5]. Thapiyal N, Joshi U, Vaibhav G, Sayana A, Srivastava AK, Jha RS. Pilomatrixoma mimicking small round cell tumor on fine needle aspiration cytology: a case report. Acta Cytol. 2008;52:627-30.

[6]. Sivakumar S. Pilomatrixoma as a diagnostic pitfall in fine needle aspiration cytology: a case report. Acta Cytol. 2007;51:583-5.

[7]. Elder DE, Elenitsas R, Jaworsky C, Johnson BL, Murphy GF. Lever's histopathology of the skin. Philadelphia: Lippincott-Raven. 2004:879.

[8]. Sánchez Sánchez C, Giménez Bascuñana A, Pastor Quirante FA, Montalbán Romero MS, Campos Fernández J, Sola Pérez J, et al. Mimics of pilomatrixomas in fine-needle aspirates. Diagn Cytopathol. 1996;14:75-83.

[9]. Kaddu S, Kerl H. Appendage tumors of the skin. In: Freedberg IM, Eisen AZ, Wolff K, Austen KF, Goldsmith LA, Katz SI, editors. Fitzpatrick's dermatology in general medicine. 6th ed. New York: McGraw-Hill; 2003. pp. 785-808.

[10]. Thapiyal N, Joshi U, Vaibhav G, Sayana A, Srivastava AK, Jha RS. Pilomatrixoma mimicking small round cell tumor on fine needle aspiration cytology: a case report. Acta Cytol. 2008;52:627-30. 
[11]. Greene RM, McGuff HS, Miller FR. Pilomatrixoma of the face: a benign skin appendage mimicking squamous cell carcinoma. Otolaryngol Head Neck Surg. 2004;130:483-5.

[12]. Kovacic M, Rudic M, Nekic I, Lisica-Sikic N, Kranjcec Z, Simurina T. Giant pilomatrixoma (benign calcifying epithelioma of Malherbe) of the neck and face. Dermatol Surg. 2007;33:340-3.

[13]. 13.Act Cytol.1998 may - june :42(3):769-71

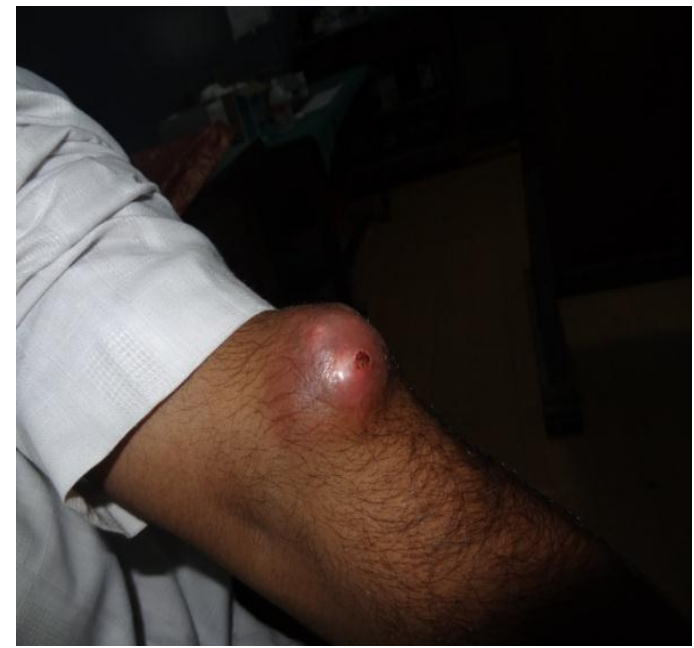

Fig . 1 shows a swelling in the left lateral forearm

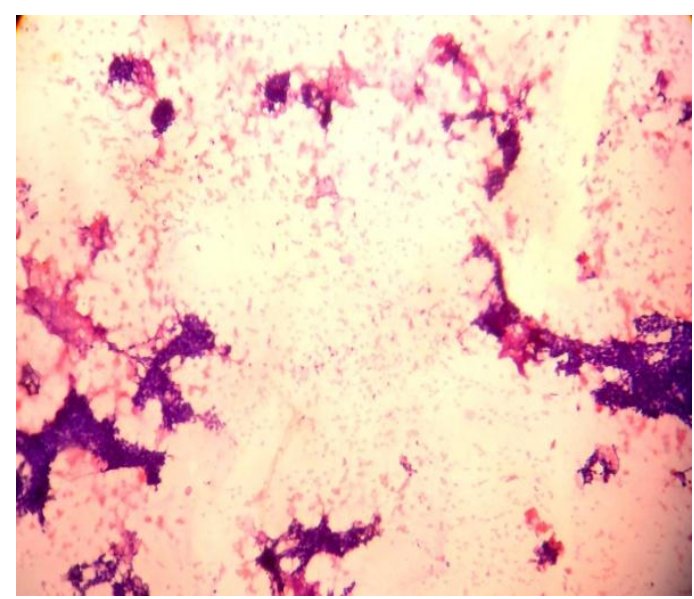

Fig 2.cytology picture of low power view shows basaloid cells and anucleated squames.

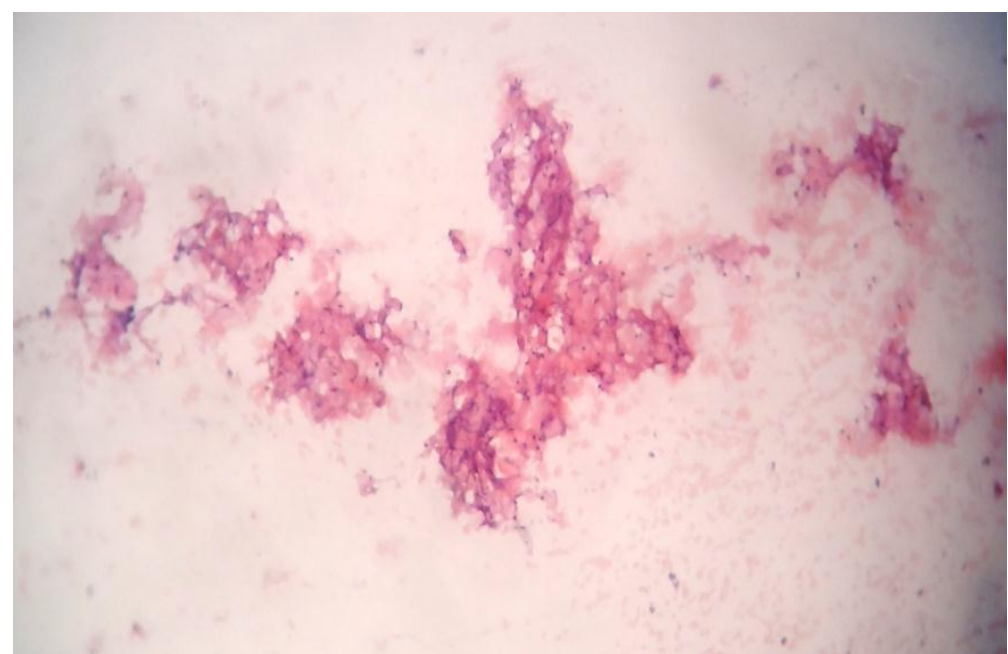

Fig 3 . low power view shows anucleated squames 


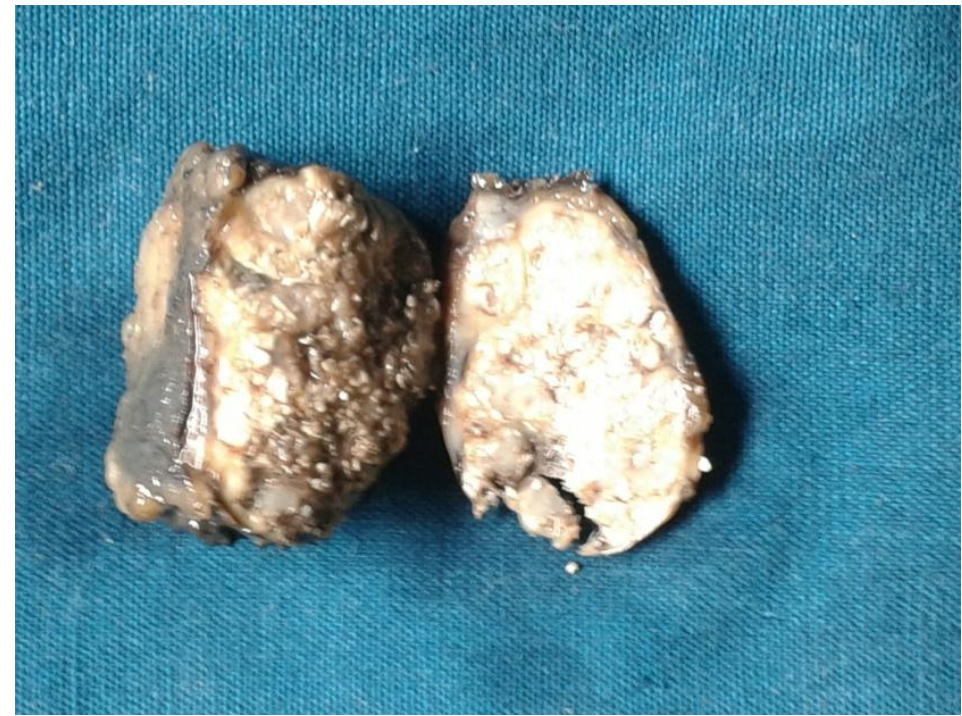

Fig 4.shows gross pictrure of pilomatricoma and cut surface shows areas of calcification

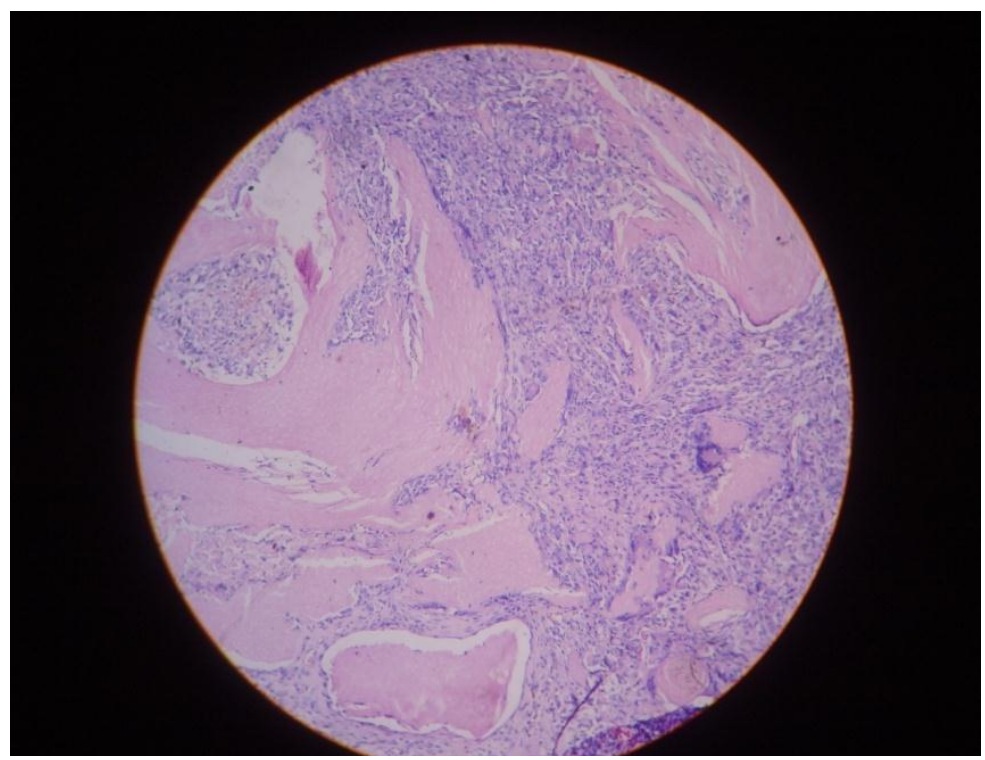

Fig 5. Low power view of $\mathrm{H} \& \mathrm{E}$ section of shows basaloid cells and anucleated squames 